\title{
Formulation of Effective Microbial Consortia and its Application for Sewage Treatment
}

\author{
S Monica, L Karthik, S Mythili and A Sathiavelu*
}

School of Biosciences and Technology, VIT University, Vellore, India

\begin{abstract}
The present study was conducted for sewage treatment using effective microbial consortium. The Effective Microorganisms (EM) like Lactobacillus, Pseudomonas, Aspergillus, Saccharomyces and Streptomyces were isolated from respective sources. The microbial consortium was formulated using molasses as medium at $\mathrm{pH} 3.8$ and incubated at $37^{\circ} \mathrm{C}$ for 3 days. The sewage treatment was carried out with the addition of $3 \mathrm{ml} / \mathrm{I} \mathrm{EM}$ solution under aerobic condition. The BOD, COD, TDS and TSS were reduced by $85 \%, 82 \%, 55 \%$, and $91 \%$ respectively after 3 days of treatment. The results showed that the formulated EM was efficient for sewage treatment and thereby it reduced the environmental impact.
\end{abstract}

Keywords: Effective Microorganisms; Molasses; Optimization; Sewage; BOD; COD; TDS; TSS

\section{Abbreviation: EM: Effective Microorganisms \\ Introduction}

Sewage treatment is one of the major problems faced by municipalities. Sewage is the wastewater comprising $99.9 \%$ water and $0.1 \%$ solid particles. The domestic sewage has high amount of organic and inorganic pollutants [1]. The untreated sewage causes foul smell [2]. The improper disposal of sewage causes pollution and destroys the aquatic organisms due to high organic content and biological oxygen demand (BOD) concentration [3]. So, the sewage has to be treated to reduce the environmental impact. The chemically treated water causes harmful effects due to toxic chemicals than the organisms which are originally present in the sewage [4]. The organisms present in wastewater degrade organic matter [5] and helps for further treatment. In conventional treatment method, bacteria remove the organic content of wastewater but the solid particle remains as sludge. The sludge can be used as fertilizer or incinerated, disposed into ocean or landfill. The conventional sewage treatment processes are expensive to operate and maintain [6] and causes pollution.

Effective Microorganism (EM) is the consortia of beneficial and naturally occurring microorganisms which are not chemically synthesized or genetically modified. The EM technology was developed by Professor Dr. Teruo Higa at University of Ryukus, Okinawa, Japan in 1970s. The EM solution is the blending of effective microorganisms in molasses at low $\mathrm{pH}$. Initially EM was developed to increase the crop yield by enhancing the soil activity [7]. But later, it has its application in wastewater treatment [8]. The EM has its wide application in the field of agriculture, natural farming, livestock, gardening, composting [9], bioremediation [10], algal control and prawn culture. The EM suppresses soil borne pathogen and pest, promotes plant growth, improves soil fertility and yield of crops and used as feed additive for livestock. The EM treated sludge is used as fertilizer and the EM treated waste water is used in crop production as it is enriched with beneficial microorganisms [11].

The EM secretes organic acids and enzymes which acts on sewage and degrades complex organic matter into simpler ones [12]. The antioxidant substances produced by EM enhances the breakdown of solids and reduces the sludge volume [13]. Missouri river in Jefferson City, North America was polluted by run off from industries and cities and generates foul odour. The application of EM for one month reduced the foul odour [14]. In Thailand, EM was sprayed 3 to 4 times on 3000-4000 metric tons of garbage which were dumped daily at a site just outside Bangkok in Ladkra Bhan. The EM reduced the foul odour and flies [10].

The EM used in this study comprises Lactobacillus, Pseudomonas, Aspergillus, Saccharomyces and Streptomyces. The lactic acid bacteria enhance the breakdown of organic matter such as lignin and cellulose. Yeast produces antimicrobial substances and their metabolites are used as substrate for lactic acid bacteria and actinomycete. The bioactive substance produced by yeast promotes plant growth. Pseudomonas releases bioactive compounds which act on the sewage and precipitates or detoxifies the metal. Aspergillus decomposes organic matter rapidly and produces alcohol, esters and antimicrobial substances. Actinomycete produces antimicrobial substances from amino acids derived from organic matter for suppressing harmful fungi and bacteria.

The main objective of this study was to develop low cost and ecofriendly sewage treatment process using effective microbial consortia.

\section{Materials and Methods}

\section{Collection of samples}

The respective samples were collected for isolation of various microorganisms. The curd sample was used for isolation of Lactobacillus. The oil spilled soil and moist soil at the depth of $10 \mathrm{~cm}$ was aseptically collected in a sterile polythene bag from VIT University, Vellore, Tamil Nadu for isolation of Pseudomonas and Streptomyces, respectively. The dry yeast granules were used for isolation of Saccharomyces. The boiled rice sample was maintained in closed container for 3 days under sterile condition until the fungal mat was observed and used as inoculum for isolation of Aspergillus. The samples were refrigerated at $4^{\circ} \mathrm{C}$ for further use.

${ }^{*}$ Corresponding author: Sathiavelu Arunachalam, Assistant Professor (Senior) Environmental Biotechnology Division, School of Bio Sciences and Technology, VIT University, Vellore, TN - 632 014, India, Tel: 09443457024; E-mail: asathiavelu@vit.ac.in

Received September 06, 2010; Accepted April 25, 2011; Published April 28, 2011

Citation: Monica S, Karthik L, Mythili S, Sathiavelu A (2011) Formulation of Effective Microbial Consortia and its Application for Sewage Treatment. J Microbial Biochem Technol 3: 051-055. doi:10.4172/1948-5948.1000051

Copyright: ( 2011 Monica S, et al. This is an open-access article distributed unde the terms of the Creative Commons Attribution License, which permits unrestricted use, distribution, and reproduction in any medium, provided the original author and source are credited 


\section{Isolation of effective microorganisms}

The curd sample and oil spilled soil sample were serially diluted, $10^{-4}$, $10^{-5}$ and $10^{-6}$ dilutions of sample were inoculated on de Man Rogosa Sharpe Agar and King's B Agar and incubated at $37^{\circ} \mathrm{C}$ for 24 hours to isolate Lactobacillus and Pseudomonas, respectively. The moist soil sample was serially diluted, $10^{-3}, 10^{-4}$ and $10^{-5}$ dilutions were inoculated on Kenknight's Agar and incubated at $37^{\circ} \mathrm{C}$ for 3 days to isolate Streptomyces. The obtained inoculum from rice was inoculated on Czapek's Dox Agar by hyphal tip technique and incubated at $28^{\circ} \mathrm{C}$ for 3 days to isolate Aspergillus. The loop full of inoculum was inoculated on Potato Dextrose Agar and incubated at $37^{\circ} \mathrm{C}$ for overnight period to isolate Saccharomyces. The obtained colonies were subcultured to get pure culture as described by Cappuccino and Sherman [15].

\section{Characterization of effective microorganisms}

The isolates were identified by morphological and biochemical studies. Biochemical tests like catalase test, oxidase test, IMViC test, sugar fermentation tests, Triple Sugar Iron test, urease test and hydrolysis tests were performed as described by Cappuccino and Sherman [15].

\section{Formulation of EM}

The isolated microorganisms were cultured together in a medium (molasses) at various $\mathrm{pH}$, temperature and concentration of molasses. The optimal physical conditions for formulating EM was analysed by culturing microbial consortia at $\mathrm{pH}$ of $6.5-8$, temperature of $28^{\circ} \mathrm{C}$ and $37^{\circ} \mathrm{C}$ and molasses concentration of $1-10 \%$.

\section{Sewage treatment using EM}

The raw sewage sample was collected from VIT University, Vellore, Tamil Nadu. The floating particles were removed from sample and collected in a clean container. The container was washed using sodium hypochlorite and water followed by rinsing of sample before collection. 20 litres of sewage water was collected, divided into six equal parts and maintained one as control and rest five for inoculating different concentrations of EM. The pH, total dissolved solids (TDS), total suspended solids (TSS), biological oxygen demand (BOD) and chemical oxygen demand (COD) of sample were analysed according to the standard protocol of APHA [16] within 2 hours of collection. Then the formulated EM solution was added to sewage at various concentration ranged from 1-10 ml/l. The EM inoculated water was analysed daily to determine the effect of EM in treating sewage.

\section{Statistical analysis}

All the experiments were done in triplicates. The data was analysed statistically using Microsoft Excel 2007 and reported as mean \pm standard deviation (SD).

\section{Results and Discussion}

\section{Characterization of EM}

The isolated microorganisms were characterized according to Bergey's manual (Table 1). Erdogrul and Erbilir [17] stated that Lactobacillus is gram positive rods, catalase and oxidase negative. Pseudomonas was identified as gram negative motile rods and showed positive for catalase, oxidase and citrate tests [18]. Praveen and Jain [19] reported that Streptomyces is gram positive rods and can hydrolyse casein. The species of Streptomyces exhibited variation in colour of substrate mycelium depending on the media composition [20].

\section{Formulation of EM}

Effect of $\mathbf{p H}$ and temperature: The growth of EM was observed at $\mathrm{pH}$ of 6.5 to 8 and temperature of $28^{\circ} \mathrm{C}$ and $37^{\circ} \mathrm{C}$. The Pseudomonas may grow in a wide $\mathrm{pH}$ range of $4-10$ at $27^{\circ} \mathrm{C}$ and $37^{\circ} \mathrm{C}$ but the optimal condition is $\mathrm{pH} 8$ and $37^{\circ} \mathrm{C}$ [21]. The fungal species isolated from Antarctic soil was observed to grow at temperature between $4^{\circ} \mathrm{C}$ and $35^{\circ} \mathrm{C}$ and exhibited variation in growth pattern [22]. Praveen and Jain [19] stated that Streptomyces sampsonii shows its growth at $\mathrm{pH}$ of 5-10 and temperature of $15-42^{\circ} \mathrm{C}$.

Effect of molasses concentration: The growth of microbial consortia was observed at various molasses concentration of $1-10 \%$. The lowest concentration of molasses facilitated the growth of EM and the increased concentration inhibited the growth and survival of EM. It is observed from Table 2 that $1 \%$ to $3 \%$ of molasses is favourable for

\begin{tabular}{|c|c|c|c|c|c|}
\hline Characteristics & Lactobacillus & Pseudomonas & Saccharomyces & Aspergillus & Streptomyces \\
\hline Colony morphology & White, mucoid & Fluorescent, mucoid & $\begin{array}{l}\text { Creamy white, mucoid, } \\
\text { smooth }\end{array}$ & Black fuzzy mat & White, dry, powdery \\
\hline Cell shape & Rods & Rods & Ovoid budding cells & $\begin{array}{l}\text { Conidia arising from } \\
\text { conidiophore }\end{array}$ & Filamentous rods \\
\hline Gram stain & Gram positive & Gram negative & & & Gram Positive \\
\hline Motility & Non-motile & Motile & & & \\
\hline Catalase & - & + & & & \\
\hline Oxidase & - & + & & & \\
\hline Indole production & - & - & & & \\
\hline Methyl Red & - & - & & & \\
\hline Voges-Proskauer & - & - & & & \\
\hline Citrate utilization & - & + & & & \\
\hline Glucose fermentation & + & - & + & - & \\
\hline Lactose fermentation & + & - & + & - & \\
\hline Sucrose fermentation & + & - & + & - & \\
\hline Triple Sugar Iron & Acid butt, acid slant & Alkaline butt, alkaline slant & & & \\
\hline Urease & - & + & & & \\
\hline Casein hydrolysis & & & & & + \\
\hline Tyrosine hydrolysis & & & & & + \\
\hline Xanthine hydrolysis & & & & & + \\
\hline
\end{tabular}

Table 1: Characteristics of effective microorganisms. 
EM. The growth of Lactobacillus and Saccharomyces was observed even at highest molasses concentration of $10 \%$. The growth inhibition may be due to osmotic pressure created by molasses.

Effect of incubation period: The incubation period has greatest effect on microbial consortia formulation. At longer incubation period, the growth of microorganisms was inhibited due to depletion of nutrients, accumulation of toxic end products and change in $\mathrm{pH}$. The optimal incubation period was 72 hours as growth of all the five organisms was observed (Table 3).

The $\mathrm{pH}$ is an important parameter for preparation of EM solution. Figure 1 depicts the variation in $\mathrm{pH}$ of EM solution during incubation. The $\mathrm{pH}$ was decreased from 7 to 2.9 in 5 days of incubation by fermenting the molasses. After 5 days of incubation, the $\mathrm{pH}$ was constant as the organisms utilised the entire energy source and there was no further growth of organisms. The organisms was not able survive at high acidic $\mathrm{pH}$; hence EM solution was used after 3 days of incubation ( $\mathrm{pH} 3.8$ ).

\section{Analysis of EM treated sewage}

Biological oxygen demand: The EM reduced the BOD of sewage from 374.5 to $55.9 \mathrm{mg} / \mathrm{l}$ with mean reduction of $85 \%$. The EM showed the effective result when compare to control while treated at a concentration of $3 \mathrm{ml} / \mathrm{l}$ for 3 days. The control showed the decrease in BOD from 374.5 to $248.6 \mathrm{mg} / \mathrm{l}$ in 5 days (Figure 3). The acetogenic bacteria strain BP103 reduced the BOD by $58.5-82.2 \%$

\begin{tabular}{|l|l|l|l|l|l|l|}
\hline Name Of Organism & $\mathbf{1 \%}$ & $\mathbf{2 \%}$ & $\mathbf{3} \%$ & $\mathbf{4} \%$ & $\mathbf{5 \%}$ & $\mathbf{1 0 \%}$ \\
\hline Lactobacillus & + & + & + & + & + & + \\
\hline Pseudomonas & + & + & + & + & - & - \\
\hline Aspergillus & + & + & + & + & + & - \\
\hline Saccharomyces & + & + & + & + & + & + \\
\hline Streptomyces & + & + & + & - & - & - \\
\hline \\
+ = present, - = absent & & & & & &
\end{tabular}

Table 2: Effect of molasses concentration.

\begin{tabular}{|l|l|l|l|l|l|}
\hline Name Of Organism & $\begin{array}{l}\text { Day 1 } \\
\text { (24 hrs) }\end{array}$ & $\begin{array}{l}\text { Day 2 } \\
\mathbf{( 4 8} \text { hrs })\end{array}$ & $\begin{array}{l}\text { Day 3 } \\
\mathbf{( 7 2} \text { hrs })\end{array}$ & $\begin{array}{l}\text { Day 4 } \\
\mathbf{9 6} \text { hrs })\end{array}$ & $\begin{array}{l}\text { Day5 } \\
\mathbf{( 1 2 0 ~ h r s ) ~}\end{array}$ \\
\hline Lactobacillus & + & + & + & + & + \\
\hline Pseudomonas & + & + & + & - & - \\
\hline Aspergillus & + & + & + & + & - \\
\hline Saccharomyces & + & + & + & + & + \\
\hline Streptomyces & - & + & + & - & - \\
\hline
\end{tabular}

+ = present, - = absent

Table 3: Effect of incubation period

pH of EM solution

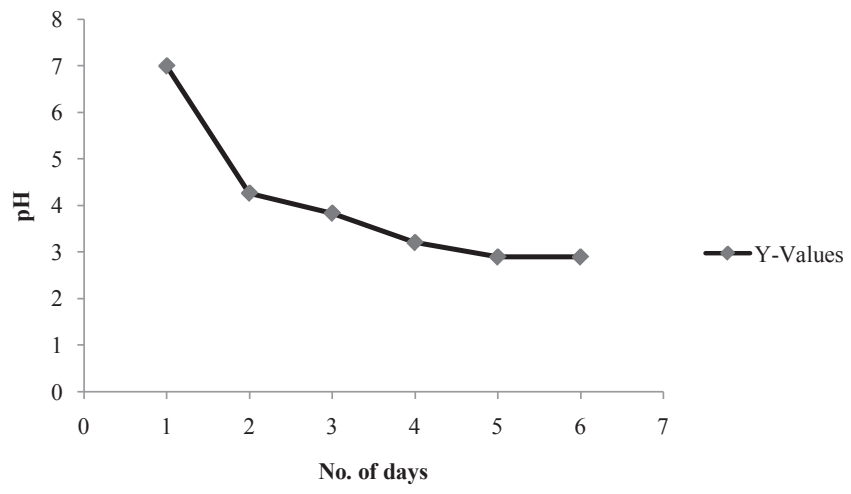

Figure 1: Impact of incubation period on $\mathrm{pH}$ of EM solution.

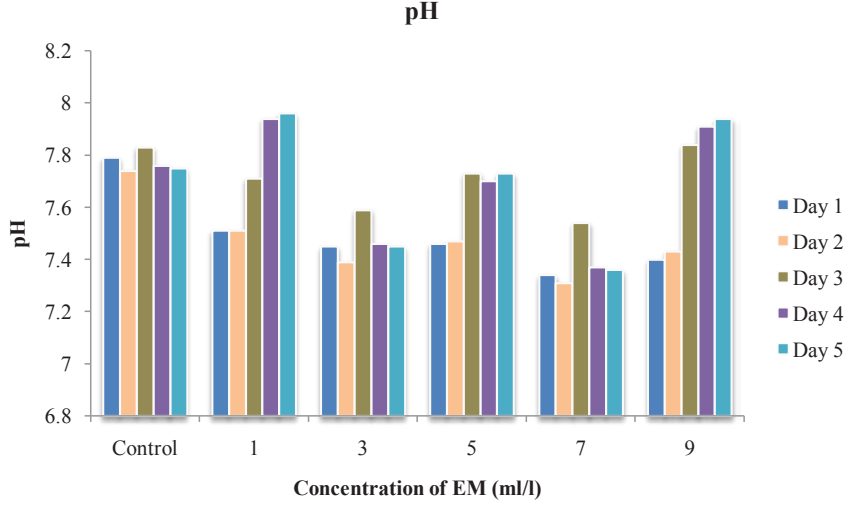

Figure 2: Effect of EM treatment on $\mathrm{pH}$ of sewage.

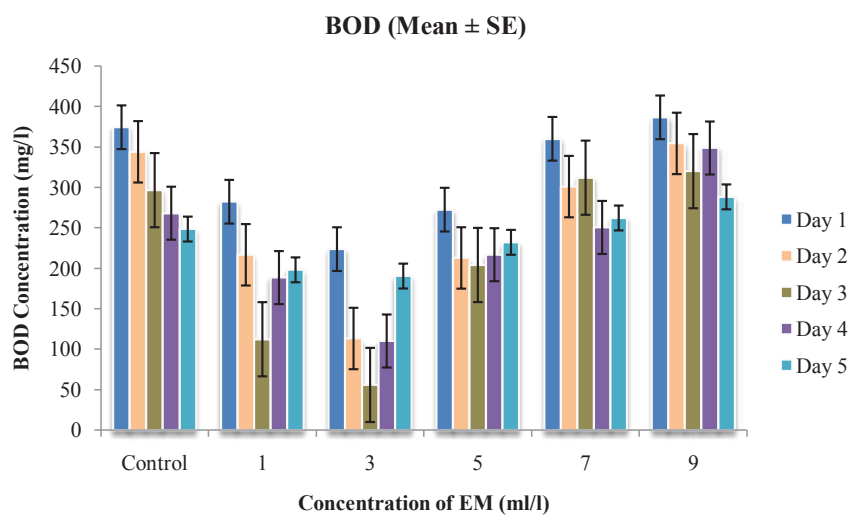

Figure 3: Effect of EM treatment on BOD reduction of sewage.

[23]. Mongkolthanaruk and Dharmsthiti [24] formulated bacterial consortium including Pseudomonas, Bacillus and Acinetobacter using molasses for treating lipid rich wastewater and the consortium reduced BOD from 448 to $72 \mathrm{mg} / \mathrm{l}$. Kumar [25] used the bacterial consortium of Pseudomonas aeruginosa, Bacillus megaterium and Stenotrophomonas maltophilia for treating paper and pulp mill effluent and observed BOD reduction from 87 to $89 \%$.

Chemical oxygen demand: The EM reduced the COD of sewage from 570.4 to $99.8 \mathrm{mg} / \mathrm{l}$ with mean reduction of $82 \%$. The EM reduced the COD effectively while treated at concentration of $3 \mathrm{ml} / \mathrm{l}$ for 3 days. The control showed the decrease in COD from 570.4 to $409.3 \mathrm{mg} / \mathrm{l}$ in 5 days (Figure 4). The EM reduced the COD of wastewater from Nestle and Trebor companies to $76 \%$ in 11 days at a concentration $1 \mathrm{ml} / \mathrm{l}$ [26]. The acetogenic bacteria strain BP103 reduced the COD by $35.5-71.2 \%$ [23]. Stanley [27] reported that whey disposed from cheese manufacturing industry was treated using Kluyveromyces fragilis which reduced the COD by $29 \%$ and $37 \%$ in 16 and 20 hours, respectively after the growth of culture. Kumar [25] used the bacterial consortium of Pseudomonas aeruginosa, Bacillus megaterium and Stenotrophomonas maltophilia for treating paper and pulp mill effluent and observed COD reduction from $67 \%$ to $71 \%$. The consortium of five white-rot fungi, Phanerochaete chrysosporium, Pleurotus ostreatus, Lentinus edodes, Trametes versicolor and S22 removed 71\% of lignin content and $48 \%$ of COD from wastewater [28].

Total dissolved solids: The EM reduced the TDS of sewage from 
2460 to $1084 \mathrm{mg} / \mathrm{l}$ with mean reduction of $55 \%$. The EM showed the effective reduction of TDS while treated at concentration of $3 \mathrm{ml} / \mathrm{l}$ for 3 days. The control showed the decrease in TDS from 2460 to $2309 \mathrm{mg} / \mathrm{l}$ in 5 days (Figure 5).

Total suspended solids: The EM reduced the TSS of sewage from 486.6 to $43.3 \mathrm{mg} / \mathrm{l}$ with mean reduction of $91 \%$. The EM showed the effective reduction of TSS while treated at concentration of $3 \mathrm{ml} / \mathrm{l}$ for 3 days. The control showed the decrease in TSS from 486.6 to $433 \mathrm{mg} / \mathrm{l}$ in 5 days (Figure 6). The acetogenic bacteria strain BP103 reduced the total solid content by $59.1 \%$ [23]. Okuda and Higa [8] used EM to reduce the total solid content of wastewater by $94 \%$.

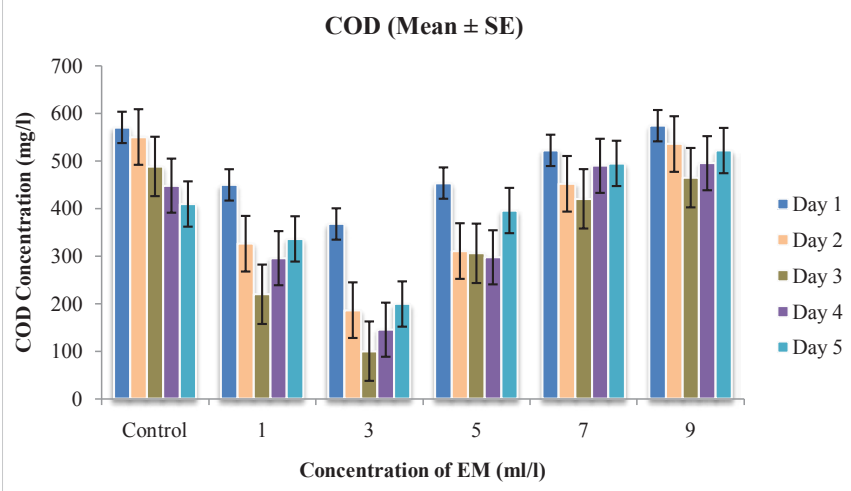

Figure 4: Effect of EM treatment on COD reduction of sewage.

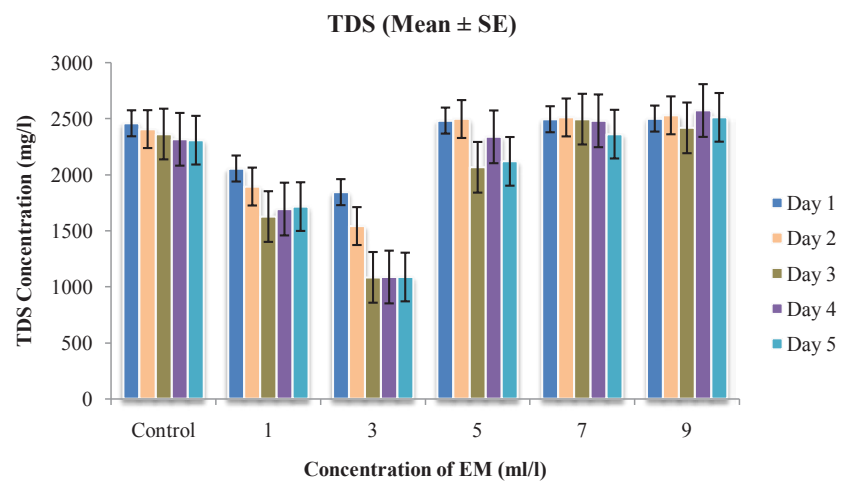

Figure 5: Effect of EM treatment on TDS reduction of sewage.

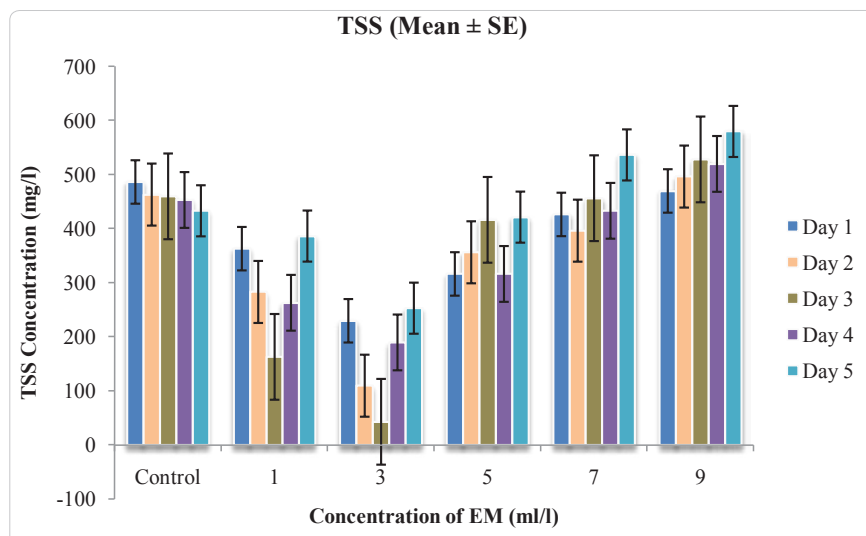

Figure 6: Effect of EM treatment on TSS reduction of sewage.
pH: The EM did not show any considerable change in $\mathrm{pH}$ of sewage. The fluctuation in $\mathrm{pH}$ was due to the natural environmental factors (Figure 2).

At higher concentration of EM, the $\mathrm{BOD}$ and $\mathrm{COD}$ was increased due to high microbial population. Hence $3 \mathrm{ml} / \mathrm{l}$ is the efficient concentration of EM for the effective treatment of sewage. After 3 days of treatment, the dissolved oxygen was decreased due to depletion of nutrients. So the treated water has to be left for chlorination.

The white rot fungi and brown rot fungi in presence of glucose reduced the BOD and COD of wastewater. If Streptomyces is cultured along with these fungi there was increase in the decolourisation to $85 \%$ [29]. The microorganisms exhibit efficient treatment in consortium than the sole organism.

The COD, BOD, TDS and TSS reduction of domestic wastewater by sedimentation, aeration, activated sludge and sand filter was $92.17 \%$, $97.66 \%, 32.38 \%$ and $97.58 \%$, respectively [30]. The sludge released by these process causes environmental impact and also it is expensive. But there is no release of sludge in EM treatment and the sewage can be treated economically.

\section{Conclusion}

The Effective Microbial consortium was formulated and its efficiency for sewage treatment was studied. The results showed that the EM treatment of sewage reduced BOD, COD, TDS and TSS by $85 \%$, $82 \%, 55 \%$ and $91 \%$ respectively. The malodour and turbidity of sewage was reduced. The treatment process is highly viable and economical. The EM treated water is non-toxic and safe to dispose as it contains beneficial microorganisms. The EM reduces the environmental impact of conventional methods.

\section{Acknowledgement}

Authors wish to thank management of VIT University, Vellore, TN, India, for providing necessary facilities and support for the completion of this work.

\section{References}

1. Elliot HA (1986) Land application of municipal sewage sludge. Journal of Soil and Water Conservation 41: 5-10.

2. Kulkarni GJ (1997) Water supply and sanitary engineering. $10^{\text {th }}$ ed. Farooc Kitab Ghar Karachi pp497.

3. Ronald MA, Richard B (1981) Microbial Ecology Fundamental and application Addison-Wesley Publishing Company Sydney pp560.

4. Kurihara $H$ (1990) Water quality of reusing waste water. Journal of Japan Sewage Works Association 27: 38-41

5. Taylor C, Yahner J, Jones D, Dunn A (1997) Wastewater Pipeline. 8.

6. Mazumder D, Roy B (2000) Low cost options for treatment and reuse of municipal wastewater. Indian J Environ Prot 20: 529-532.

7. Higa T, Parr JF (1994) Beneficial and Effective Microorganisms for a Sustainable Agriculture and Environment. International Nature Farming Research Centre, Atami, Japan, pp16.

8. Okuda A, Higa T (1995) Purification of Waste Water with Effective Microorganisms and its Utilization in Agriculture, University of the Ryukyus, Okinawa, Japan.

9. Daly MJ, Arnst B (2005) The use of an innovative microbial technology (EM) fo enhancing vineyard production and recycling waste from the winery back to the land, The $15^{\text {th }}$ IFOAM Organic World Congress Adelaide.

10. Miyajima M, Nagano N, Higa T (1995) Suppression of dioxin generation in the garbage incinerator, using EM (Effective Microorganisms), EM-Z, and EM-Z ceramics Powder, College of Agriculture, University of Ryukyus.

11. Higa T (1996) Effective Microorganisms -Their role in Kyusei Nature Farming and sustainable agriculture. In Proceedings of the Third International Conference on Kyusei Nature Farming. Washington, USA pp20-24. 
Citation: Monica S, Karthik L, Mythili S, Sathiavelu A (2011) Formulation of Effective Microbial Consortia and its Application for Sewage Treatment. J Microbial Biochem Technol 3: 051-055. doi:10.4172/1948-5948.1000051

12. Freitag DG (2000) The use of Effective Microorganisms (EM) in Organic Waste Management.

13. Higa T, Chinen N (1998) EM Treatments of Odor, Waste Water and Environmental Problems College of Agriculture University of Ryukyus Okinawa Japan.

14. da Silva AB, Sanches AB, Kinjo S (1997) Use of Effective Microorganisms for treatment of domestic sewage by the activated sludge process. Mokichi Ohada Foundation Ipeuna SP Brazil.

15. Cappuccino JG, Sherman N (1996) Microbiology - a Laboratory Manual 159201.

16. Anon (1992) Standard methods of water and wastewater examination $18^{\text {th }} \mathrm{Ed}$, American Public Health Association NW Washington, DC 2-127.

17. Erdogrul O, Erbilir F (2006) Isolation and characterization of Lactobacillus bulgaricus and Lactobacillus casei from Various Foods. Turk J Biol 30: 39-44.

18. Hussein H, Moawad H, Farag S (2004) Isolation and characterization of Pseudomonas resistant to heavy metals contaminants. Arab J Biotech 7: 1322.

19. Jain PK, Jain PC (2007) Isolation characterization and antifungal activity of Streptomyces sampsonii GS 1322 Indian. J Exp Biology 45: 203-206.

20. Hassan AM, YI El-Shahed K, El-Monaem A, El-Nakkadi M (2009) Isolation, screening and identification of newly isolated soil Streptomyces (Streptomyces sp. NRC-35) for $\beta$-Lactamase inhibitor production. World Applied Science Journal 5: 637-646.
21. Murad S, Hasan F, Ali Shah A, Hameed A, Ahmed S (2007) Isolation of phthalic acid degrading Pseudomonas sp. p1 from soil. Pak J Bot 39: 1833-1841

22. Kostadinova N, Krumova E, Tosi S, Pashova, Angelova M (2009) Isolation and identification of filamentous fungi from island Livingston Antarctica Biotechno $11^{\text {th }}$ anniversary scientific conference. pp267-270.

23. Sirianuntapiboon S, Phothilangka P, Ohmomo S (2004) Decolourization of molasses wastewater by a strain No. BP 103 of acetogenic bacteria. Bioresour Technol 92: pp31-39.

24. Mongkolthanaruk W, Dharmsthiti S (2002) Biodegradation of lipid-rich wastewater by a mixed bacterial consortium. Int Biodeterior Biodegradation 50: 101-105.

25. Kumar A, Kumar R, Tiku DK, Sharma P, Chaturvedi R (2007) Biological process for reducing chemical and biochemical oxygen demand of pulp and paper industrial effluent. United States Patent 7267772-B2.

26. Gede Ngurah Wididana (1994) Preliminary experiment of EM technology on wastewater treatment Indonesian Kyusei Nature Farming Society Indonesia.

27. Gilliland SE (1979) Measuring Chemical Oxygen Demand of Cottage Cheese Whey cultured with Kluyveromyces fragilis. J Dairy Sci 62: 882-887.

28. Juan Wu, Xiao YZ, Yu HQ (2005) Degradation of lignin in pulp mill wastewaters by white-rot fungi on biofilm. Bioresour Technol 96: 1357-1363.

29. Bowling M, Adams P (2003) Method of wastewater treatment utilizing white rot and brown rot fungi, United States patent.

30. Al-Jlil S (2009) COD and BOD reduction of waste water using activated sludge sand filters and activated carbon in Saudi Arabia. Biotechnol 8: 473-477. 